\title{
Expression of Integrin-Associated Protein Gene Associated with Memory Formation in Rats
}

\author{
A-Min Huang, ${ }^{1,2}$ Hai Long Wang, ${ }^{2}$ Yu Ping Tang, ${ }^{1}$ and Eminy H. Y. Lee ${ }^{1}$ \\ 1/nstitute of Biomedical Sciences, Academia Sinica, Taipei, Taiwan, Republic of China, and ${ }^{2}$ Graduate Institute of Life \\ Sciences, National Defense Medical Center, Taipei, Taiwan, Republic of China
}

\begin{abstract}
The present study has adopted the PCR differential display method to identify cDNA clones associated with memory formation in rats. The one-way inhibitory avoidance learning task was used as the behavioral paradigm. Total RNA isolated from the hippocampus of poor-memory (<80 sec) and goodmemory $(600 \mathrm{sec})$ rats $3 \mathrm{hr}$ after training was used for comparison. Three cDNA fragments corresponding to different spliced forms of integrin-associated protein (IAP) mRNA were found to be differentially expressed in the hippocampus of goodmemory rats. Quantitative reverse transcription-PCR revealed approximately four fold higher of IAP mRNA level in goodmemory rats. This result was confirmed further by in situ hybridization analysis, and the major difference was in the dentate gyrus. It has been demonstrated that this difference in IAP mRNA expression is not attributable to different sensitivities of
\end{abstract}

individual rats to electric shock. Rapid amplification of cDNA ends obtained the full-length IAP cDNA, which is $1192 \mathrm{bp}$ in length excluding the poly $\left(\mathrm{A}^{+}\right)$tail. The IAP mRNA expression was significantly upregulated by NMDA and amphetamine injections to the dentate gyrus of the hippocampus. On the other hand, injection of antisense oligonucleotide complementary to the IAP transcript markedly impaired memory retention in rats and decreased the amplitude and slope of EPSP in the in vivo long-term potentiation paradigm. These results together suggest that IAP gene expression plays an important role in memory formation and synaptic plasticity in rat hippocampus.

Key words: PCR differential display; integrin-associated protein; inhibitory avoidance learning; memory formation; longterm potentiation; hippocampus
A number of studies have revealed that there are many forms of memory. According to the temporal parameter, memory can be divided into at least two distinct forms: short-term memory and long-term memory. Short-term memory lasts for minutes to hours, whereas long-term memory persists for several hours to days, weeks, and even years (Goelet et al., 1986). Two lines of evidence suggest that long-term memory, but not short-term memory, requires de novo RNA and protein synthesis. The first one is that inhibition of protein or mRNA synthesis impairs long-term memory (Davis and Squire, 1984). The second one is that long-term memories are believed to be stored by modification of preexisting synapses or formation of new synaptic connections (Weiler et al., 1995). This evidence indicates that the neural activities associated with learning lead to the expression of various genes, the protein products of which play a critical role in memory formation. Extensive efforts have been made to identify specific gene expression related to long-term memory formation. With the use of two-dimensional gel analysis, Castellucci et al. (1988) identified several proteins that are related to the process of long-term sensitization for the gill-withdrawal reflex in the sea plug Aplysia. Screening of Drosophila mutants has yielded approximately 10 genes that are specific to the processes of olfactory learning and memory (Tully, 1996). These methods are effective; however, they take a long time to identify and characterize the specific genes.

\footnotetext{
Received Dec. 8, 1997; revised March 5, 1998; accepted March 10, 1998.

This work was supported by a research fund from the Institute of Biomedical Sciences, Academia Sinica, Taipei, Taiwan, Republic of China.

Correspondence should be addressed to Dr. Eminy H. Y. Lee, Institute of Biomedical Sciences, Academia Sinica, Taipei 115, Taiwan, Republic of China. Copyright (C) 1998 Society for Neuroscience 0270-6474/98/184305-09\$05.00/0
}

In the present study, we have used the PCR differential display method (Liang and Pardee, 1992) to identify gene expression related to memory formation in rats. The general strategy of this method is to amplify partial cDNA sequences from subsets of mRNAs by reverse transcription (RT) and PCR. Pairs of primers were used in the PCR amplification: one is a degenerate anchor primer that anneals to the $\operatorname{poly}\left(\mathrm{A}^{+}\right)$tail, and the other is arbitrary in sequence and hybridizes at different positions relative to the anchor primer. The amplified PCR products are then displayed on a sequencing gel, and the differentially expressed genes can be rapidly identified. An inhibitory avoidance learning task was used as the behavioral paradigm. Previous pharmacological and biochemical studies have shown that the hippocampus is involved in this form of learning (Lee et al., 1993; Cammarota et al., 1995; Izquierdo et al., 1995). More related to the present study, injection of protein or mRNA synthesis inhibitors into the dentate gyrus of the hippocampus significantly impaired memory consolidation in rats (Lee et al., 1992). Using the PCR differential display method, we have found that one of these genes related to memory formation encodes the rat integrin-associated protein (IAP). IAP was first characterized in human placental tissue and hematopoetic cells (Brown et al., 1990). Subsequent analyses showed that an Rh complex-related glycoprotein CD47 (Mawby et al., 1994) and an ovarian tumor marker OA3 (Campbell et al., 1992) are the same as IAP. These observations suggest that IAP may have different functions in different tissues. In the present study we provide the first evidence that IAP gene expression in the hippocampus is associated with memory consolidation and synaptic plasticity in rats.

\section{MATERIALS AND METHODS}

Animals. Adult male Sprague Dawley rats (220-300 gm) bred in the Animal Facility of the Institute of Biomedical Sciences, Academia Sinica, 
were used. Animals were housed in a room maintained at $23 \pm 2{ }^{\circ} \mathrm{C}$ and a $12 \mathrm{hr}$ light/dark cycle (light on at 6:30 A.M.). Food and water were available ad libitum.

Inhibitory avoidance learning task. A one-way inhibitory avoidance learning task was used to measure retention performance in rats. The apparatus consists of a trough-shaped alley divided by a sliding door into an illuminated safe compartment and a dark compartment. A shock generator with facilities to vary current is connected to the floor of the dark compartment. The behavioral task included the training and testing procedures and was conducted between 10:00 A.M. and 5:00 P.M. Before experimentation, rats were kept in a dim room for $1 \mathrm{hr}$ to adjust to the environment. On the training phase, the rat was placed at the far end of the illuminated compartment facing away from the door. As the rat turned around, the door was opened. When the rat entered the dark compartment, the door was closed and a $1.0 \mathrm{~mA} / 1 \mathrm{sec}$ footshock was given. The rat was then removed from the alley and returned to its home cage. Three hours later, the retention test was given. The rat was again placed into the illuminated compartment, and the latency to step into the dark compartment was recorded as the measure of retention performance. Rats that did not enter the dark compartment and reached the ceiling score of $600 \mathrm{sec}$ were removed from the alley and assigned as good-memory rats. Rats with a retention latency $<80 \mathrm{sec}$ were assigned as poor-memory rats. Sixty-eight rats were trained. Eleven rats that showed poor memory and eleven rats that showed good memory were chosen for further experiments. The remaining rats showing a retention latency between 80 and $600 \mathrm{sec}$ were not used in the present study. Five untrained rats and four rats that received only electric shock without going through the training procedure were used for the control experiment. In assessing the effects of IAP antisense oligonucleotide on memory retention (see below), we subjected the rats to the same behavioral training and testing procedures, and the retention score for each rat was recorded.

Tissue dissection and total RNA extraction. Animals were decapitated immediately after the retention test. Their brains were removed and placed in ice-cold saline for $5 \mathrm{~min}$ and then sliced on an ice-cold platform. Bilateral hippocampal tissues were dissected out, frozen on dry ice, and stored at $-80^{\circ} \mathrm{C}$ until use. Total RNA was isolated from the hippocampus of each rat using $1 \mathrm{ml}$ of the Ultraspec RNA isolation solution according to the instruction of the manufacturer (Biotecx Laboratories, Houston, TX). DNase treatments were performed to remove DNA contamination. Twenty micrograms of total RNA were incubated at $37^{\circ} \mathrm{C}$ for $30 \mathrm{~min}$ with $2 \mathrm{U}$ of ribonuclease inhibitor (Promega, Madison, WI), 2 U of DNase I (Promega) in $10 \mathrm{~mm}$ Tris-C1, pH 9.0, $50 \mathrm{~mm} \mathrm{KCl,}$ $1.5 \mathrm{mM} \mathrm{MgCl}_{2}$, and $0.1 \%$ Triton $\mathrm{X}-100$. The reaction was stopped by extraction with phenol/chloroform $(3: 1)$, and the supernatant was precipitated with $2 \mathrm{vol}$ of ethanol in the presence of $0.25 \mathrm{M}$ potassium acetate. RNA was then redissolved in an appropriate volume of DEPCtreated water. Optical densities of $\mathrm{OD}_{260}$ and $\mathrm{OD}_{280}$ were used to estimate the quantity and purity of the isolated total RNA.

PCR differential display. PCR differential display analysis was performed according to the original method (Liang and Pardee, 1992; Liang et al., 1993) with minor modifications. Total RNA $(1.0 \mu \mathrm{g})$ was incubated at $70^{\circ} \mathrm{C}$ for $10 \mathrm{~min}$ with $2 \mu \mathrm{l}$ of one of the degenerate oligo dT primers $(25 \mu \mathrm{M})\left(\mathrm{T}_{12} \mathrm{VA}, \mathrm{T}_{12} \mathrm{VC}, \mathrm{T}_{12} \mathrm{VG}\right.$, and $\mathrm{T}_{12} \mathrm{VT}$; V $=\mathrm{A}, \mathrm{C}$, or $\mathrm{G}$ ) (synthesized by Genosys Biotechnologies, The Woodlands, TX) and DEPC $\mathrm{H}_{2} \mathrm{O}$ to a final volume of $9 \mu \mathrm{l}$, and subsequently kept on ice for $5 \mathrm{~min}$. Four microliters of $5 \times$ synthesis buffer, $1 \mu \mathrm{l}$ of $200 \mu \mathrm{M}$ dNTP mix, $2 \mu \mathrm{l}$ of 0.1 $\mathrm{M}$ dithiothreitol (DTT), $0.28 \mu \mathrm{l}$ of RNasin (40 U/ $\mu \mathrm{l}$ ) (Promega), and $1 \mu \mathrm{l}$ of Superscript II Moloney murine leukemia virus reverse transcriptase $(200 \mathrm{U} / \mu \mathrm{l})($ Life Technologies/BRL, Grand Island, NY) were added to the mixture and incubated at $37^{\circ} \mathrm{C}$ for $60 \mathrm{~min}$. The reaction was terminated by heating the sample at $80^{\circ} \mathrm{C}$ for $10 \mathrm{~min}$. Two microliters of the reverse-transcribed products were added into $18 \mu \mathrm{l}$ of the PCR reaction mixtures containing $50 \mathrm{mM} \mathrm{KCl}, 10 \mathrm{~mm}$ Tris-Cl, $\mathrm{pH} 8.8$ at $25^{\circ} \mathrm{C}, 1.0 \mathrm{~mm}$ $\mathrm{MgCl}_{2}, 0.1 \%$ Triton X-100, $4 \mu \mathrm{M}$ dNTP, $0.5 \mu \mathrm{M}\left[{ }^{35} \mathrm{~S}\right] \mathrm{dATP}$ (Amersham, Buckinghamshire, UK), and 1 U of Tag DNA polymerase (Promega). Thirty short arbitrary primers (purchased from Genosys Biotechnologies) were used for the PCR reactions. The PCR parameters were $94^{\circ} \mathrm{C}$ for $30 \mathrm{sec}, 40^{\circ} \mathrm{C}$ for $1 \mathrm{~min}$, and $72^{\circ} \mathrm{C}$ for $30 \mathrm{sec}$ for 40 cycles followed by a final elongation at $72^{\circ} \mathrm{C}$ for $5 \mathrm{~min}$. An aliquot of $5.7 \mu \mathrm{l}$ of the PCR products was mixed with $2.3 \mu \mathrm{l}$ of sequencing loading buffer and separated on $6.0 \%$ polyacrylamide gels. Differentially expressed cDNA fragments were recovered from the sequencing gels, reamplified with the same set of primer pairs, and cloned into the pGEM-T vector using the TA cloning system (Promega). Plasmid DNA containing the correct

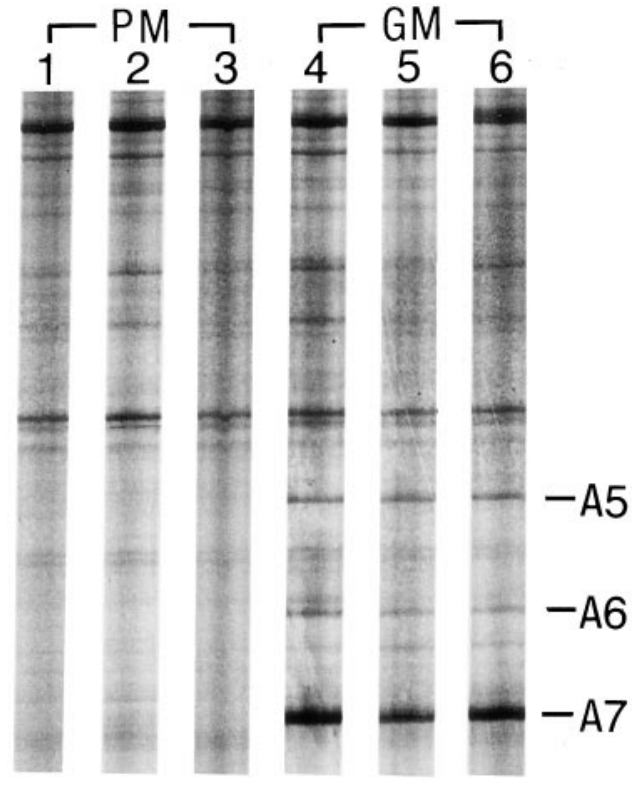

Figure 1. PCR differential display of rat hippocampal RNA associated with retention performance of inhibitory avoidance learning. Total RNA isolated from the hippocampus of poor-memory $(P M)$ and good-memory $(G M)$ rats was subjected to differential display analysis using $5^{\prime}$ oligonucleotide Ldd8 (5'-AGC CAG CGA A-3') and 3' oligonucleotide $\mathrm{T}_{12} \mathrm{VA}$ as the primer set. Radiolabeled PCR products were analyzed with a $6.0 \%$ polyacrylamide gel. Differentially expressed cDNA fragments-A5, A6, and A7 cDNA bands, among three poor- and three good-memory ratsare illustrated.

inserts was sequenced using the ABI Prism dye terminator kit and an ABI 373 sequencer (Applied Biosystems, Foster City, CA). The nucleotide sequences obtained were compared with known sequences by searching GenBank and European Molecular Biology Laboratory databases with the Fasta Program (Genetic Computer Group).

Rapid amplification of $c D N A$ ends cloning. Rapid amplification of cDNA ends (RACE) cloning strategy (Frohman et al., 1988) was used to obtain the full-length rat IAP cDNA. Specific oligonucleotides were designed from the common sequence of A5, A6, and A7 fragments identified by PCR differential display. RACE reactions were performed with the Marathon cDNA amplification kit from Clontech Laboratories according to the manufacturer's instructions. One microgram of hippocampal poly $\left(\mathrm{A}^{+}\right)$RNA from an untreated rat was subjected to cDNA synthesis and one-fiftieth of the RACE-ready cDNA was used as template in the 5'RACE or 3'RACE PCR reactions. 5'RACE reactions were performed with a gene-specific primer (GSP1) (see Fig. 2A) and Anchor Primer (Clontech Laboratories). Dilutions of the primary PCR amplification were used for secondary PCR reactions using a nested gene-specific primer (GSP2) (see Fig. 2A) and another Anchor Primer. Products of the secondary PCR reactions were analyzed by a $1.5 \%$ agarose gel and three cDNA fragments $(\sim 1000,700$, and $400 \mathrm{bp})$ were visualized on the ethidium bromide-stained gel. These products were cloned into the pGEM-T vector (Promega), and clones containing the 1000,700 , or $400 \mathrm{bp}$ insert were sequenced from both directions using the ABI373 sequencer. The 1000 or 700 bp clone contains the sequence of A5 fragment (Fig. 1), and the 400 bp clone contains the sequence of the A6 fragment (Fig. 1). 3'R ACE reactions were performed with another gene-specific primer (GSP3) (Fig. 2A) and Anchor Primer. A 300 bp fragment was obtained, which was identical to the sequence of A5 fragment. The rat IAP cDNA obtained by this RACE cloning strategy was $1160 \mathrm{bp}$ in length, which did not contain the 5' untranslation region and an initiation codon by comparison with the mouse IAP cDNA sequence (GenBank, accession number Z25524). Further cloning was performed by using an oligonucleotide corresponding to the $5^{\prime}$ end of mouse IAP cDNA (mIAP: 5'-CCC GGG CAG CCT GGG CGG CCG CTC CTG-3') and an oligonucleotide to the $5^{\prime}$ end of the $1160 \mathrm{bp}$ cDNA (GSP4) (Fig. 2A). Oligonucleotides used for PCR analysis of the IAP gene were synthesized by Genosys Biotechnologies.

In situ hybridization. We performed an in situ hybridization experiment 
A

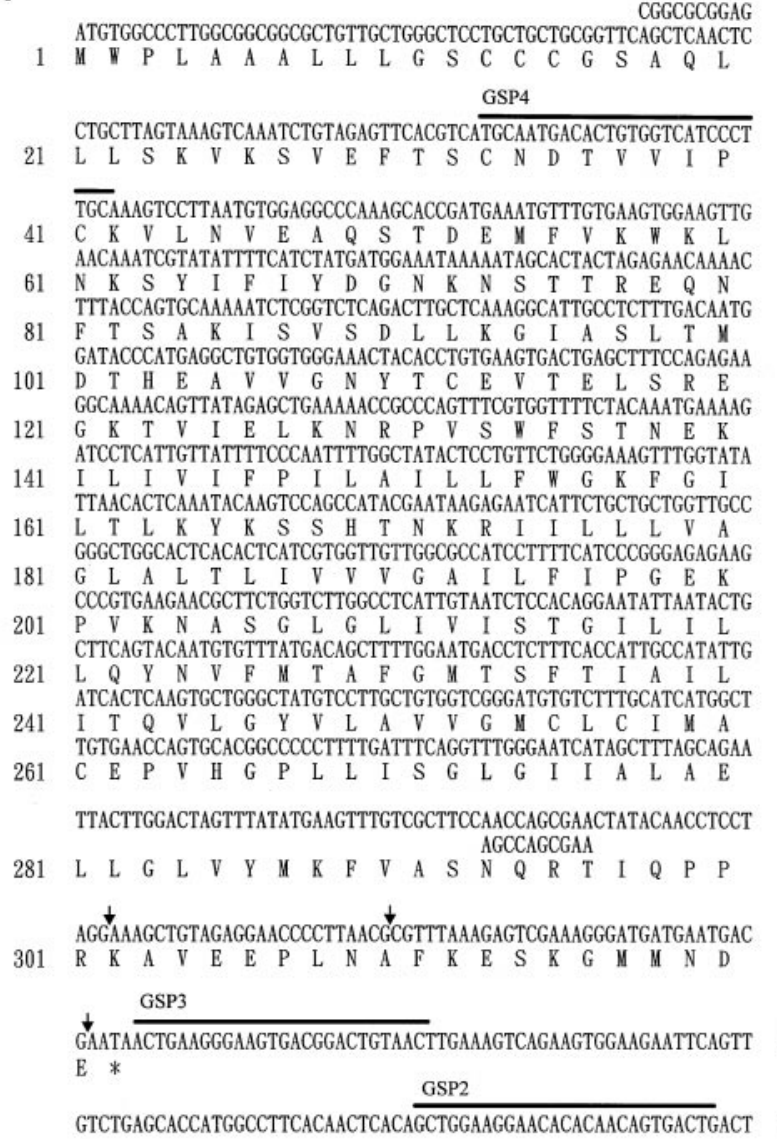

TTCATCTCTGAAAAAAGTCATTGAACCATAAATGAATATTACAGTTAAGTTTATATTAAA

1140

GSP1

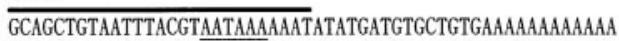
AVTTTTTTTTTTTT

\section{B}

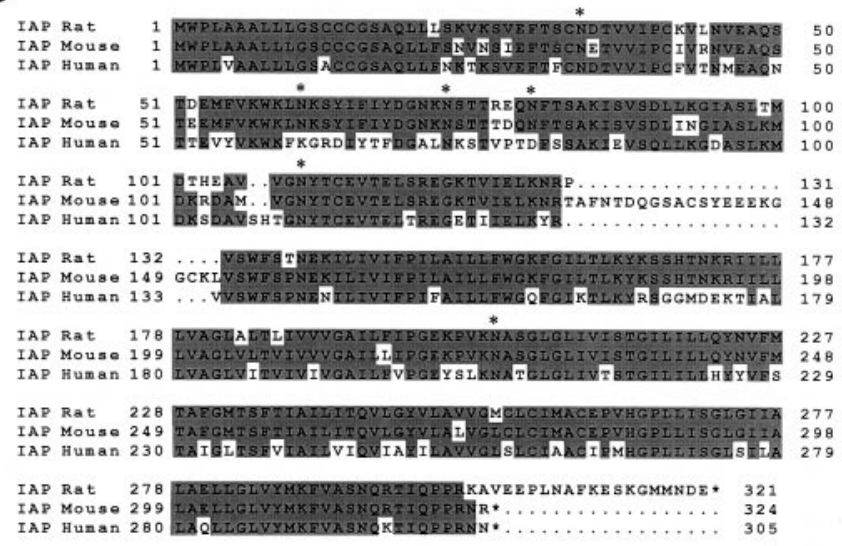

Figure 2. Nucleotide and deduced amino acid sequence of rat IAP cDNA. $A$, Nucleotide sequence of rat IAP cDNA. Nucleotides are numbered relative to the start of the initiation codon. The putative poly $\left(\mathrm{A}^{+}\right)$ addition site (AATAAA) is underlined. The location of sites at which the 5' [nucleotide (nt) 868-877] and 3' (nt 1172-1185) PCR differential display primers hybridized are also shown. Gene-specific primers used for RACE cloning are shown. The deduced amino acid sequence is shown in a one-letter IUPAC code, starting with the initiator methionine. The splicing sites that generate form 2, form 3, and form 4 rat IAP are indicated by arrows. This sequence has been assigned accession number AF017437 by GenBank. B, Alignment of amino acid sequence among rat, to evaluate expression of the IAP mRNA in rat hippocampus after the inhibitory avoidance learning. The in situ hybridization protocol used was slightly modified from the previous study (Tang et al., 1997). Three hours after the retention test, animals were anesthetized with pentobarbital (40 mg/kg, i.p.) and perfused intracardially with $150 \mathrm{ml}$ of heparinized $0.1 \mathrm{M}$ PBS, pH 7.4, followed by $150 \mathrm{ml}$ of $4 \%$ paraformaldehyde in $0.1 \mathrm{M}$ PBS. Brains were removed and stored at $-80^{\circ} \mathrm{C}$ until they were sectioned. Serial sections at $20 \mu \mathrm{m}$ thickness through the hippocampus from six good-memory and four poor-memory rats were cut on a cryostat, thaw-mounted onto poly-1-lysine-coated slides, and vacuum-desiccated overnight. Slides were stored in boxes containing desiccant at $-80^{\circ} \mathrm{C}$ until in situ hybridization was performed. In situ hybridization was performed using a 46-base synthetic oligonucleotide (5'-CCA CTT CAC AAA CAT TTC ATC GGT GCT TTG GGC CTC CAC ATT AAG G-3'). This oligomer is complementary to the cloned rat IAP cDNA (bases 129-174) and was synthesized and purified by Genosys Biotechnologies. The probe $(15 \mathrm{pmol} / \mu \mathrm{l})$ was $3^{\prime}$ end-labeled by incubating at $37^{\circ} \mathrm{C}$ for $15 \mathrm{~min}$ with ${ }^{35}$ S-dATP (Amersham) and terminal deoxynucleotidyl transferase (25 U; Boehringer Mannheim, Indianapolis, IN) to a specific activity of $\sim 10^{6}$ $\mathrm{cpm} / \mu \mathrm{l}$. Prehybridization treatment of tissue consisted of warming the sections to room temperature and rinsing in $20 \times \mathrm{SSC}$ for $10 \mathrm{~min}$ at room temperature. For hybridization, the labeled IAP oligonucleotide probe $\left(1 \times 10^{6} \mathrm{cpm} / \mathrm{slide}\right)$ in $100 \mu \mathrm{g} / \mathrm{ml}$ yeast transfer RNA, $500 \mu \mathrm{g} / \mathrm{ml} \mathrm{salmon}$ sperm DNA, and Denhardt's solution (0.02\% Ficoll, $0.02 \%$ polyvinylpyrrolidone, and $0.02 \%$ bovine serum albumin) was applied to each slide. Slides were coverslipped with parafilm, and hybridization proceeded for $24 \mathrm{hr}$ at $42^{\circ} \mathrm{C}$. Coverslips were then removed, and sections were rinsed in $2 \times \mathrm{SSC}$ and then in $1 \times \mathrm{SSC}$ containing $1.0 \mathrm{M}$ (DTT, $0.1 \%)$, followed by $30 \mathrm{~min}$ wash in $0.5 \times \mathrm{SSC}$ containing $1.0 \mathrm{M}$ DTT at $47^{\circ} \mathrm{C}$. A final wash in $0.5 \times \mathrm{SSC}$ containing $1.0 \mathrm{M}$ DTT was performed at room temperature for $30 \mathrm{~min}$. The slides were dehydrated through a series of ethanols and dipped in emulsion (NTB-3, Kodak, Rochester, NY) diluted 1:1 with distilled water. After a 3 week exposure period, slides were developed in Kodak D-19 developer.

Quantitative RT-PCR analysis. Quantitative RT-PCR analysis was used to determine the relative amount of IAP mRNA from various treatments. RT reactions were performed as described above (see PCR differential display), except that $10 \mathrm{~mm} \mathrm{dNTP}$ and $0.5 \mu \mathrm{g} / \mu \mathrm{l}$ of oligo $\mathrm{d}(\mathrm{T})_{15}$ were used. The rat hypoxanthine phosphoribosyl transferase (HPRT) mRNA was used as an internal control template that was coamplified with the IAP mRNA. Synthetic primers 5'-CTC TGT GTG CTG AAG GGG GG-3' and 5'-GGG ACG CAG CAA CAG ACA TT-3' were used to detect HPRT mRNA (Jansen et al., 1992) and GSP1 and GSP3 primers (Fig. $2 A$ ) for IAP mRNA. One-twentieth of the RT products was then added to a $20 \mu \mathrm{l}$ PCR solution containing the same reaction buffer as described above: $0.2 \mathrm{mM}$ each of dGTP, dCTP, and dTTP, 0.1 mM dATP, $0.1 \mu \mathrm{M}$ HPRT primers, $0.2 \mu \mathrm{M}$ IAP primers, $1.0 \mathrm{U}$ of Tag DNA polymerase, and $0.5 \mu \mathrm{M}\left[{ }^{35} \mathrm{~S}\right] \mathrm{dATP}$ (Amersham). The cycling parameters were $94^{\circ} \mathrm{C}$ for $30 \mathrm{sec}, 60^{\circ} \mathrm{C}$ for $1 \mathrm{~min}$, and $72^{\circ} \mathrm{C}$ for 30 sec for 39 cycles followed by a final elongation at $72^{\circ} \mathrm{C}$ for $5 \mathrm{~min}$. Eighteen microliters of the PCR products were analyzed on a native $9 \%$ polyacrylamide gel and autoradiographed on the imaging plate of a phosphoimage analyzer (Phosphoimager, Molecular Dynamics, Sunnyvale, CA). Quantification of the radioactivity of each cDNA band was performed according to the instruction manual. For establishment of the standard curve, $0.125-2.0 \mu \mathrm{g}$ of total RNA was reverse-transcribed. One-twentieth of the RT products was PCR-amplified and analyzed. For comparisons of samples from different drug treatments, $0.5 \mu \mathrm{g}$ of total RNA was used.

IAP $m R N A$ expression after intra-dentate gyrus drug administration. Pharmacological studies have shown that drugs such as amphetamine and NMDA were effective in enhancing memory performance of inhibitory avoidance learning in rats (Lee et al., 1993; Lee and Ma, 1995). This experiment therefore was designed to examine the effects of these drugs on IAP mRNA expression in the hippocampus. Rats were subjected to stereotaxic surgery and drug infusions as described previously (Huang and Lee, 1995). Briefly, two 23 gauge stainless steel thin-wall cannulae

\section{$\leftarrow$}

mouse, and human IAP. Sequences are numbered starting with the initiator methionine. The amino acid sequences are given with gaps introduced during the alignment indicated by dots. Amino acids are shadowed where the residues of two or three sequences are identical at any given position. Potential N-linked glycosylation sites in the rat IAP are shown by asterisks above the sequence. 
(10 mm long) were implanted bilaterally into the dorsal dentate gyrus of the hippocampus $(3.6 \mathrm{~mm}$ posterior to the bregma, $2.5 \mathrm{~mm}$ lateral to the midline, and $3.0 \mathrm{~mm}$ ventral to the skull surface). Seven to $10 \mathrm{~d}$ after recovery from the surgery, animals were given bilateral intra-dentate gyrus injections of saline, amphetamine (1.6 $\mu \mathrm{g} / \mathrm{side})$, NMDA (0.03 $\mu \mathrm{g} / \mathrm{side})$, or carbachol $(0.8 \mu \mathrm{g} / \mathrm{side})$. The animals were awake and gently held by the experimenter when they were given the injections. The injection was administered through a 30 gauge injection needle connected to a $10 \mu \mathrm{l}$ Hamilton microsyringe by $0.5 \mathrm{~m}$ of polyethylene tubing (PE-20). The injection needle was bent so that when it was inserted into the cannula the needle tip would protrude $1.5 \mathrm{~mm}$ beyond the tip of the cannula. Drug solutions were introduced into the PE tubing and the microsyringe, and they were delivered into the dentate gyrus manually at a rate of $0.2 \mu \mathrm{l} / \mathrm{min}$ with a total volume of $0.8 \mu \mathrm{l}$ on each side. Amphetamine and carbachol were purchased from Sigma (St. Louis, MO). NMDA was obtained from Research Biochemical (Natick, MA). Doses refer to the salt form. Drugs were dissolved in $0.9 \%$ isotonic saline immediately before use. Thirty minutes after drug infusion, bilateral dentate gyrus tissues were dissected out using a $1.5 \mathrm{~mm}$ punch, frozen on dry ice, and stored at $-80^{\circ} \mathrm{C}$ until use. Total dentate gyrus RNA extraction and IAP mRNA detection were performed as described above.

IAP antisense oligonucleotide administration. To specifically inhibit the expression of the IAP gene, an antisense phosphorothioate derivative of the 18 mer 5'-CGC CGC CAA GGG CCA CAT-3' was synthesized complementary to nucleotides $1-18$ of the sequence of rat IAP cDNA (Fig. $2 A$ ). A random 18 mer sequence 5'-TGA GAA GAG TGA TGA CAA-3' was synthesized as a control. The phosphorothioate oligonucleotides were synthesized and purified by Genosys Biotechnologies. For the memory retention experiment, rats were randomly divided into three groups ( $n=11$ or 9 ) (see Fig. 6). Rats in all groups were subjected to stereotaxic surgery and intra-dentate injections as described above. For this experiment, $1 \mathrm{nmol}$ of IAP antisense or random sequence oligonucleotide in $1.0 \mu \mathrm{l}$ was injected into each rat four times, with $12 \mathrm{hr}$ between injections, at a rate of $0.2 \mu \mathrm{l} / \mathrm{min}$. Rats were trained $12 \mathrm{hr}$ after the last injection, and memory retention was measured $3 \mathrm{hr}$ after training. For the long-term potentiation (LTP) experiment, the IAP antisense or the random sequence was similarly injected into one side of the dentate area at a position $1.0 \mathrm{~mm}$ above the gyrus. Two injections ( $1 \mathrm{nmol})$ were given, with the first injection $16 \mathrm{hr}$ and the second injection $2 \mathrm{hr}$ before the electrophysiological recording. For each injection, $1.0 \mu \mathrm{l}$ of $1.0 \mathrm{nmol}$ antisense or random sequence was administered at a rate of $0.2 \mu \mathrm{l} / \mathrm{min}$.

Electrophysiology. The in vivo LTP recording was adopted to test the effect of IAP antisense oligonucleotide on synaptic plasticity in rats. The method used was according to that of Wayner et al. (1993) with minor modifications. Rats (250-350 gm) were anesthetized with urethane (1.4 $\mathrm{gm} / \mathrm{kg}$, i.p.) and placed on a stereotaxic instrument. Throughout the surgery and experiment, core body temperature was monitored and maintained at $35 \pm 1^{\circ} \mathrm{C}$ with a feedback control system. The skull was exposed, and electrodes were implanted through burr holes in the skull. Stimulating electrodes were platinum concentric bipolar electrodes with a tip diameter of $25 \mu \mathrm{m}$ and were positioned unilaterally to the dorsomedial perforant path at stereotaxic coordinates of $8.5 \mathrm{~mm}$ posterior and $4.4 \mathrm{~mm}$ lateral to the bregma. Recording electrodes were prepared from single-barrel glass micropipettes $(1.2 \mathrm{~mm}$ outer diameter $\times 0.6 \mathrm{~mm}$ inner diameter), pulled on a Narishige vertical puller, and filled with $3 \mathrm{M} \mathrm{NaCl}$. Resistance ranged from 1 to $3 \mathrm{M} \Omega$. The recording electrodes were implanted ipsilaterally into the dentate gyrus, $3.5 \mathrm{~mm}$ posterior to the bregma and $2.0 \mathrm{~mm}$ lateral to the midline. The stereotaxic coordinates were adjusted for variation in rat body weights and to maximize the monosynaptic responses of the population EPSPs (pEPSPs) produced by the granular cells in response to stimulation of the perforant path. Once both the recording and stimulating electrodes were positioned, $5 \%$ agar dissolved in $0.9 \% \mathrm{NaCl}$ was applied over the exposed skull to prevent surface drying and reduce movement artifacts. Stimulation consisted of $50 \mu \mathrm{sec}$ duration monophasic constant current pulses delivered once every $10 \mathrm{~min}$. Stimulus intensities ranged from 50 to $250 \mu \mathrm{A}$ and produced averaged pEPSP amplitudes of 3-5mV. Once determined, stimulus current remained constant throughout the experiment. To induce LTP, four sets of stimulus trains in a $10 \mathrm{~min}$ period were delivered after a $30 \mathrm{~min}$ baseline recording. Each set contained five trains, 10 pulses per train at $400 \mathrm{~Hz}$, delivered at a rate of one train $/ \mathrm{sec}$ for $5 \mathrm{sec}$. The pulse widths in the trains were 50,100, 150, and $200 \mu \mathrm{sec}$, respectively. The population spike amplitude, slope, and amplitude of the pEPSPs were recorded once every $10 \mathrm{~min}$.

Statistical analysis. Student's $t$ test or one-way ANOVA followed by
Dunnett's $t$ test were used for comparisons between groups for the IAP mRNA level and for the amplitude and slope of pEPSP. Because the distribution of the retention score was uneven and was truncated at 600 , nonparametric Mann-Whitney $U$ test was used to analyze the data for retention performance.

\section{RESULTS}

\section{PCR differential display analysis}

Total RNA samples extracted from the hippocampus of poor- and good-memory rats tested $3 \mathrm{hr}$ after inhibitory avoidance learning were subjected to PCR differential display analysis. Four 3'-end primers $\left(\mathrm{T}_{12} \mathrm{VA}, \mathrm{T}_{12} \mathrm{VC}, \mathrm{T}_{12} \mathrm{VG}\right.$, and $\left.\mathrm{T}_{12} \mathrm{VT}\right)$ in combination with $305^{\prime}$-end arbitrary 10-mers were used for screening. Most of the cDNA bands were identical among individuals; however, three cDNA bands, designated as A5, A6, and A7, were differentially expressed between poor-memory and good-memory rats when the $\mathrm{T}_{12} \mathrm{VA}$ and Ldd8 (5'-AGCCAGCGAA-3') were used as primer pairs (Fig. 1). Sequence comparison revealed that these three cDNA bands are identical in their 3 '-end cDNA sequences. However, at the $5^{\prime}$-end, A5 is 25 bp longer than A6, and A6 is 33 bp longer than A7. Their sequences were 80 and $70 \%$ homologous to the $3^{\prime}$-end region of the mouse IAP cDNA (accession number Z25524) and human IAP cDNA (accession number Z25521), respectively. It appears that A5, A6, and A7 cDNAs correspond to different alternative splicing forms of rat IAP mRNA. Differences among these three forms are identical to the alternative splicing forms found in human and mouse (Campbell et al., 1992; Reinhold et al., 1995). A5 corresponds to the form 4 IAP, A6 to the form 3 IAP, and A7 to the form 2 IAP (Reinhold et al., 1995).

\section{RACE cloning}

To obtain a full-length transcript of the rat IAP, the RACE cloning strategy was performed as described in Materials and Methods. Results indicated that the IAP cDNA is 1192 bases in length, excluding the poly $\left(\mathrm{A}^{+}\right)$tail (Fig. $2 A$ ). The predicted encoded polypeptide is 321 residues in length, which corresponds to the human or mouse form 4 IAP. Figure $2 B$ shows the identity in amino acid sequence among rat, mouse, and human IAP. There is $93 \%$ identity between rat and mouse IAP and $72 \%$ identity between rat and human IAP. The predicted molecular mass of IAP is $35 \mathrm{kDa}$, considerably lower than the apparent molecular mass of $50 \mathrm{kDa}$ determined for native human IAP by SDS-PAGE (Brown et al., 1990). The presence of six putative N-linked glycosylation sites (AsnXSer/Thr) (Fig. 2B) suggests that extensive glycosylation may account for the size discrepancy.

\section{In situ hybridization}

Results of in situ hybridization analyses indicated that the IAP mRNA is expressed in both the pyramidal cell layer and the dentate gyrus of the hippocampus. Although the IAP mRNA level was higher in both subdivisions of the hippocampus in good-memory rats when compared with the poor-memory controls, but the effect was more prominent in the dentate gyrus (Fig. 3).

\section{IAP mRNA level determined by quantitative RT-PCR analysis}

To further confirm the expression of hippocampal IAP in relation to memory consolidation, quantitative RT-PCR analysis was used to estimate the IAP mRNA level. Oligonucleotides corresponding to the common sequence of $\mathrm{A} 5, \mathrm{~A} 6$, and $\mathrm{A} 7 \mathrm{cDNAs}$ were used as primers, and the PCR product is $209 \mathrm{bp}$ in length (Fig. $4 A$ ). Linear relationship was established between serial amounts of hippocampal total RNA (6.25-100 ng) and the optical densities of 


\section{(A) Poor memory}

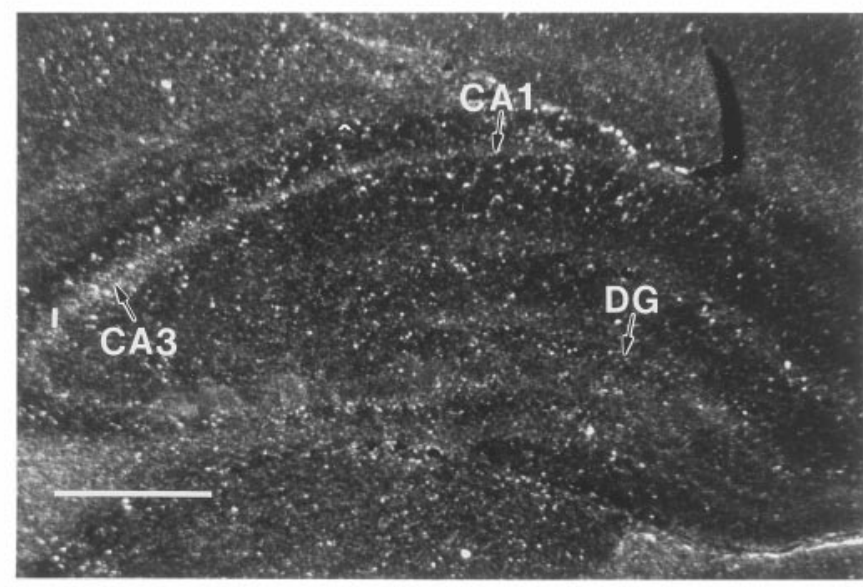

\section{(B) Good memory}

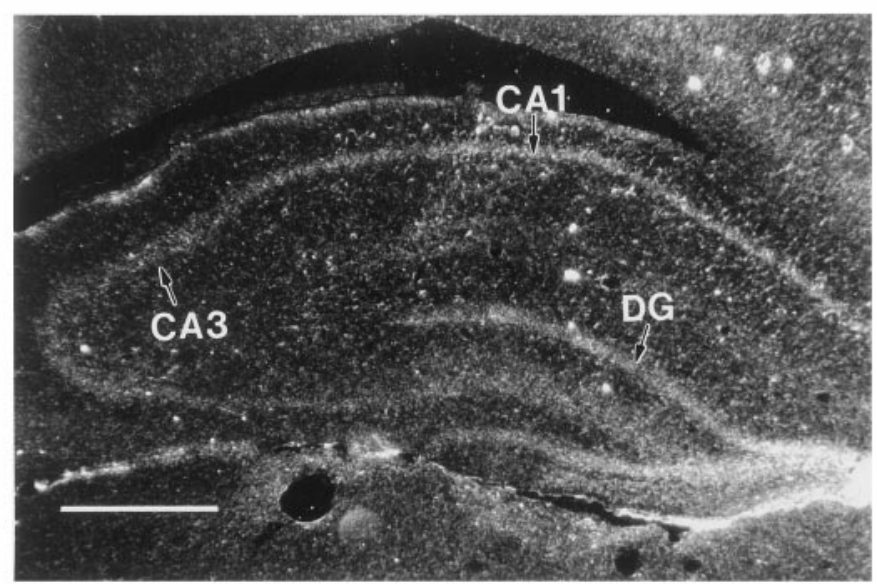

Figure 3. In situ hybridization showing a higher expression of IAP mRNA signal in the hippocampus of good-memory rats. Coronal sections through the hippocampus from $(A)$ poor-memory rats $(n=4)$ and $(B)$ good-memory rats $(n=6)$ were subjected to in situ hybridization analyses. $C A 1$, CA1 cell body layer; $C A 3$, CA3 cell body layer; $D G$, dentate gyrus. Scale bar, $500 \mu \mathrm{m}$.

the cDNA bands (Fig. 4B). Statistical analyses revealed that the IAP mRNA level was significantly higher in good-memory rats when compared with the poor-memory rats $(t=8.11 ; p<0.01)$ (Fig. 4C,D).

To demonstrate that the observed effects are not attributable to differences in the sensitivity of individual rats to electric shock, hippocampal RNA from five untrained rats and from four rats that received electric shock but not the training procedure was analyzed. Results indicated that there was not a significant difference in IAP mRNA level between these two groups of rats $(t=$ $0.11 ; p>0.75)$ (Fig. $4 E$ ). These results indicate that the difference in IAP mRNA level is not attributable to the difference in the sensitivity of the animals to electric shock.

\section{Regulation of IAP mRNA by drugs}

If IAP mRNA expression is specifically associated with memory processing, then drugs that facilitate memory performance are likely to alter IAP mRNA expression. We tested this hypothesis by directly injecting amphetamine, NMDA, and carbachol into the dentate gyrus in rats. Animals were killed 30 min after drug infusion, and their dentate gyrus tissues were dissected out and subjected to RT-PCR analysis of IAP mRNA expression. As shown in Figure 5, one-way ANOVA revealed an overall significant effect of drug treatment $(F=4.06 ; p<0.05)$. Further Dunnett's $t$ test indicated that both amphetamine and NMDA contributed to this main effect $\left(t_{\mathrm{D}}=2.32, p<0.05\right.$, and $t_{\mathrm{D}}=2.70$, $p<0.05$, respectively). Carbachol was without a significant effect $\left(t_{\mathrm{D}}=0.11, p>0.05\right)$.

\section{Effects of IAP antisense oligonucleotide on memory retention in rats}

To demonstrate that IAP mRNA expression is indeed involved in the memory process, we have assessed the effects of IAP antisense oligonucleotide treatment on memory retention in rats. As shown in Figure 6, results indicated that IAP antisense oligonucleotide administration significantly impaired retention performance in rats (Mann-Whitney $U$ test; $U=18.5, Z=2.35, p<$ 0.05 when compared with the controls). Injection of random sequence oligonucleotide did not produce a marked effect on memory retention (Mann-Whitney $U$ test; $U=58.5, Z=0.13$, $p>0.05$ when compared with the controls).

\section{Effects of IAP antisense oligonucleotide on hippocampal LTP}

To further verify that the observed increase in IAP mRNA expression is associated with memory processing, we have adopted the LTP paradigm, an electrophysiological model for learning and memory (Collingridge and Bliss, 1995), and the same antisense manipulation for the present investigation. Results indicated that IAP antisense oligonucleotide injection to the dentate gyrus markedly decreased the expression of in vivo LTP in both the amplitude (41\% decrease on the average; $t_{\mathrm{D}}=3.61$, $p<0.01$; Dunnett's $t$ test) (Fig. 7A) and slope (37\% decrease on the average; $t_{\mathrm{D}}=3.28, p<0.01$ ) (Fig. $7 B$ ) of pEPSP in the hippocampus when compared with the tetanization group. There was not a marked difference between the tetanization group and the random sequence control group regarding the amplitude of pEPSP $\left(t_{\mathrm{D}}=0.91, p>0.05\right)$ and slope of $\mathrm{pEPSP}\left(t_{\mathrm{D}}=0.52\right.$, $p>0.05)$.

\section{DISCUSSION}

IAP was first identified as a $50 \mathrm{kDa}$ glycoprotein in the human placenta and hematopoetic cells (Brown et al., 1990) and predicted as a membrane protein containing three domains: an extracellular domain, a multiple membrane-spanning domain, and an alternatively spliced intracellular domain (Lindberg et al., 1993). The belief that the cDNA cloned in this study is the rat counterpart of human or mouse IAP is based on two explanations. First, the amino acid sequence of the rat IAP is $93 \%$ identical to the mouse IAP and $72 \%$ identical to the human IAP. Second, the alternative splicing forms for the cytoplasmic tail of the rat IAP are identical to those of mouse and human. The three forms (A5, A6, and A7 in this study) of IAP identified by PCR differential display in the rat hippocampus correspond to form 4 , form 3, and form 2 of the mouse or human IAP, respectively. This evidence suggests that form 2 , form 3 , and form 4 IAP express in the rat brain.

IAP was originally named for its association with the $\beta_{3}$ class of integrins on placenta and platelets (Brown et al., 1990). Integrins were named for their links between the extracellular matrix 
A

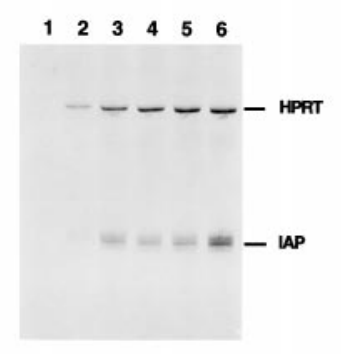

B

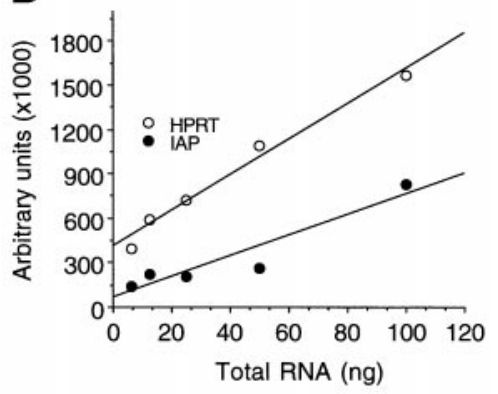

C
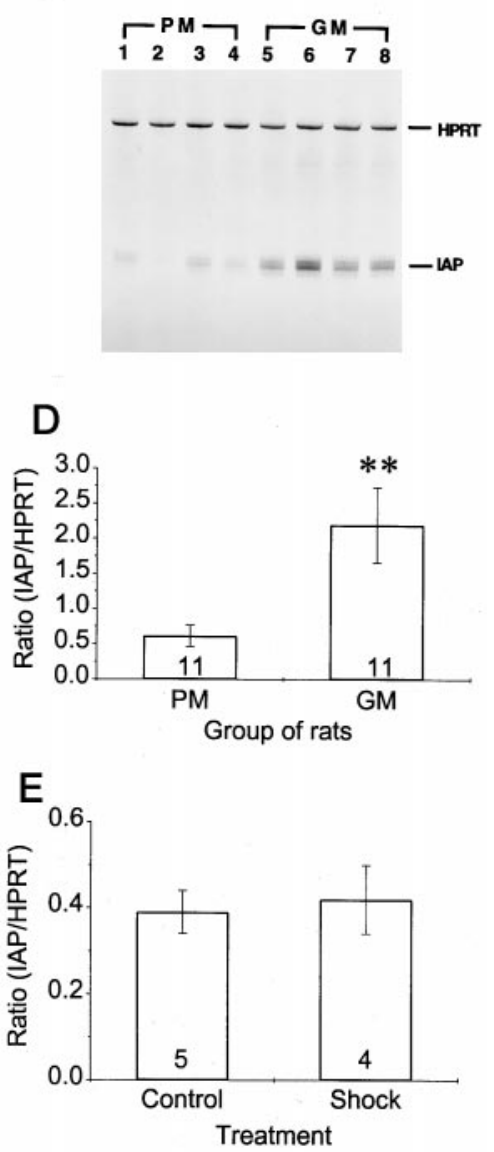

Figure 4. Quantitative RT-PCR analysis of rat IAP mRNA. A, Autoradiograph of the IAP and HPRT cDNA bands. Serial quantities $(6.25,12.5$, 25,50 , and $100 \mathrm{ng}$ ) of total hippocampal RNA were reverse-transcribed and amplified by PCR. The template of HPRT was used as an internal control. RT-PCR products were analyzed by a $9 \%$ polyacrylamide gel, visualized by a phosphoimager machine, and quantitated. $B$, Linear relationship between the optical density of the cDNA bands and the quantity of total RNA. $C$, Autoradiography of the IAP and HPRT cDNA

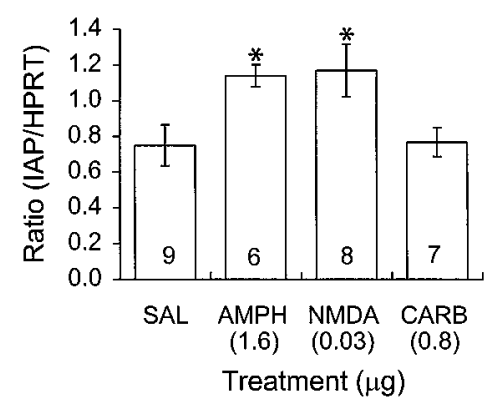

Figure 5. Drug effects on IAP mRNA level. Saline ( $S A L)$, amphetamine $(A M P H), N M D A$, or carbachol $(C A R B)$ was infused into rat dentate gyrus bilaterally at a rate of $0.2 \mu \mathrm{g} / \mathrm{min}$ and a total volume of $0.8 \mu \mathrm{l}$ on each side. The number in each column indicates the number of rats in each treatment group. Thirty minutes after drug infusion, rats were decapitated, and the bilateral dentate gyrus tissues were dissected out. Total RNA was isolated and subjected to quantitative RT-PCR analysis identical to the procedure in Figure 4. Both amphetamine and NMDA significantly increased IAP mRNA level in the hippocampus $\left({ }^{*} p<0.05\right.$; Dunnett's $t$ test).

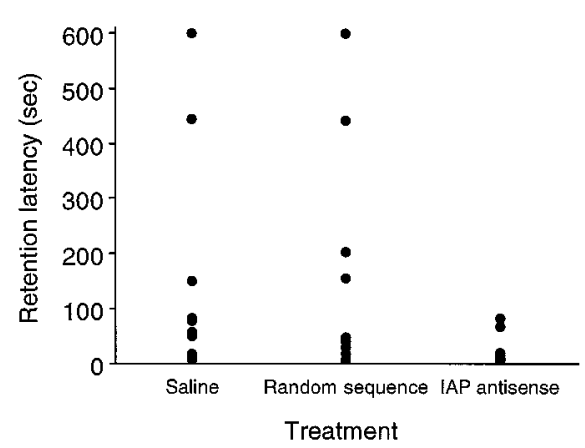

Figure 6. Effects of IAP antisense oligonucleotide on memory retention of one-way inhibitory avoidance learning in rats. The distribution of the retention score for each individual rat after saline $(n=11)$, IAP antisense oligonucleotide $(n=9)$, or random sequence $(n=11)$ treatment is shown. Four injections at intervals of $12 \mathrm{hr}$ were given before the training procedure (for details, see Materials and Methods). For each injection, 1.0 $\mu \mathrm{l}$ of saline or the oligonucleotide $(1 \mathrm{nmol})$ was injected directly into the dentate gyrus of the hippocampus bilaterally. There was a significant difference between the control group and the IAP antisense group when evaluated by the Mann-Whitney $U$ test $(p<0.05)$.

protein and cytoskeleton (Tamkun et al., 1986). In the nervous system, integrins are involved in anatomical organization during development and neurite growth in tissue cultures (Reichardt and Tomaselli, 1991; Defreitas et al., 1995). The possible involvement of integrin-like proteins in neuroplasticity was first examined by Lynch and colleagues (Staubli et al., 1990; Xiao et al., 1991), who found that antagonists for integrin-binding sites and integrin antibodies block LTP in rat hippocampal slices. Results obtained in the present study imply that the function of integrin involved in LTP and neuronal plasticity is possibly regulated by IAP. If IAP is involved in synaptic modification that occurs during mem-

bands from the poor-memory $(P M)$ and good-memory $(G M)$ rats. $D$, Higher expression of IAP mRNA level in good-memory rats $(n=11$ in each group). ${ }^{* *} p<0.01$ by Student's $t$ test. $E$, IAP mRNA expression in control animals and animals that received electric shock only. The control rats $(n=5)$ were placed in the chamber for $5 \mathrm{sec}$, returned to the home cage, and killed $3 \mathrm{hr}$ later. Rats in the shocked group $(n=4)$ received a single electric shock, were returned to the home cage, and were killed $3 \mathrm{hr}$ later. 
(A)

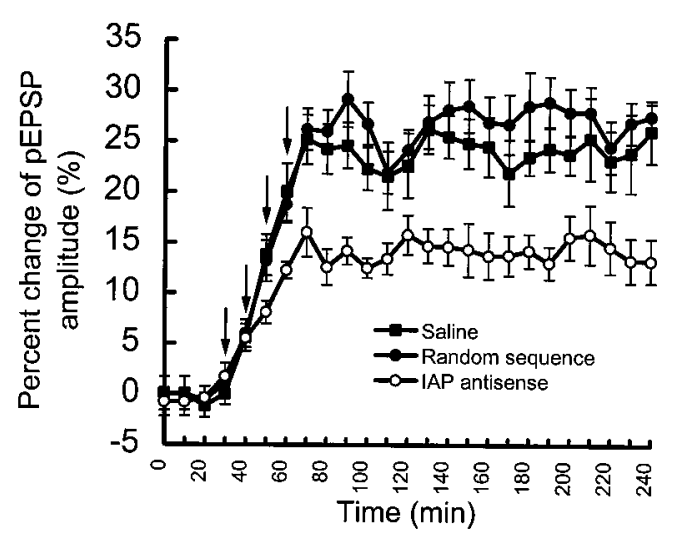

(B)

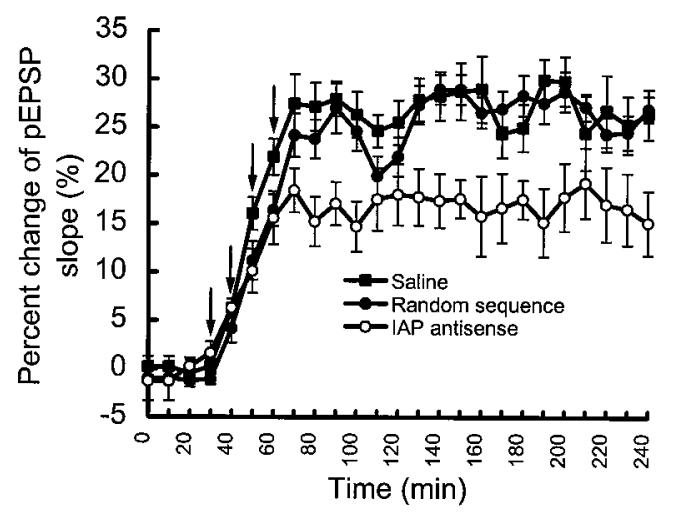

Figure 7. Effects of IAP antisense oligonucleotide on LTP in rat hippocampus. Percentage change in the $(A)$ mean amplitude and $(B)$ slope of pEPSPs and SEMs was presented as a function of time after IAP antisense oligonucleotide injection $(n=5)$ and the random sequence injection $(n=5)$ versus the tetanization controls $(n=5)$. The tetanus stimulations that yielded LTP (indicated by arrows) were given at 30, 40, 50 , and $60 \mathrm{~min}$. Each stimulation contains five trains at $400 \mathrm{~Hz}$. The duration of stimulation was $50 \mu \mathrm{sec}$ at $30 \mathrm{~min}, 100 \mu \mathrm{sec}$ at $40 \mathrm{~min}, 150$ $\mu \mathrm{sec}$ at $50 \mathrm{~min}$, and $200 \mu \mathrm{sec}$ at $60 \mathrm{~min}$, respectively.

ory formation through the integrin signaling pathway, there should be integrins on the synaptic plasma membrane (SPM) of the hippocampus. However, antibodies to $\alpha_{\mathrm{v}} \beta_{3}$ or $\alpha_{5} \beta_{1}$ integrins did not label any conventional integrin in the hippocampal SPM (Bahr et al., 1991a,b; Bahr and Lynch, 1992). These observations suggest three possible models for the involvement of hippocampal IAP in the process of memory formation. First, the association between hippocampal IAP and conventional integrins is not present in the synaptic area. Interactions between IAP and conventional integrins may affect fasciculation of neurites, which is proposed to be needed for synapse rearrangement during memory formation (Glanzman et al., 1989; Keller and Schacher, 1990). Second, hippocampal IAP may regulate the functions of a new class of integrin that is required for the process of memory formation. In the hippocampal SPM, matrix receptors with smaller molecular weights than conventional integrins and containing integrin epitopes were identified (Bahr et al., 1997). For example, a $55 \mathrm{kDa}$ synaptic protein was eluted from affinity columns by integrin antagonists and labeled by antibodies to the integrin $\alpha_{5} \beta_{1}$ (Bahr et al., 1997). IAP may be involved in regulation of the physiological functions of these unconventional integrins. Further evidence suggesting a possible association between the function of integrin and IAP comes from a recent study that a Drosophila mutant, Volado, which showed impaired memory, is also deficient in $\alpha$-integrin (Grotewiel et al., 1998). Whether there is a parallel increase in integrin expression of good-memory rats in the present study is currently under investigation. The third possibility is that a direct interaction between IAP and the extracellular matrix proteins that is independent of integrin may exist. This speculation is not surprising because IAP is expressed in some cells with no known integrins, such as erythrocyte (Brown et al., 1990). In this regard, IAP may be viewed as a kind of cell adhesion molecule the expression of which is enhanced by the process of memory formation. Some structural features confer on IAP the properties of a cell adhesion molecule. First, the extracellular domain of IAP has a single immunoglobulin variable (IgV)-like structure (Lindberg et al., 1993). The IgV-like structure is the common feature of many cell adhesion molecules in the nervous system (Yoshihara et al., 1991). One of the natural ligands for IAP was shown to be the thrombospondin-1 matrix protein, suggesting that IAP may be directly involved in cell adhesion to matrix proteins (Gao et al., 1996). Second, there are several potential glycosylation sites in IAP. Glycosylation is an important characteristic of cell adhesion molecules. In addition to being regulated at the transcriptional and translational levels (Rose, 1995; Schmidt, 1995), cell adhesion molecules modified at the post-translational level were also found to be related to the process of memory formation (Doyle et al., 1992; Fox et al., 1995; Murphy et al., 1996). Hence, glycosylation of IAP may facilitate adhesion of cell surface to the matrix. Third, the cytoplasmic tail of IAP possesses alternative splicing forms. In the cytoplasmic portion, form 4 IAP is eight amino acids longer than form 3, and form 3 is 11 amino acids longer than form 2. If the cytoplasmic tail is involved in the interaction between IAP and the cytoskeleton, differential expression of different forms of IAP may suggest the reorganization of cytoskeletons required for synaptic modification during memory formation.

In this study, we found that the IAP mRNA level was higher in good-memory rats $3 \mathrm{hr}$ after the avoidance learning. One would suspect that the high IAP mRNA level could be related to individual differences in the sensitivity of the animal to electric shock. We then examined this possibility by comparing the expression of IAP mRNA from untreated rats and rats that received electric shock only with the same parameters as used in training. No difference in IAP mRNA expression between these two groups was found, suggesting that the IAP mRNA expression in good-memory rats is not attributable to individual differences in their sensitivities to electric shock. The other possibility is that good-memory rats have constitutively higher levels of IAP. Although in the present study we have demonstrated that IAP antisense injection impaired memory retention and hippocampal LTP in rats, these results do not provide direct evidence regarding the cause-effect relationship between IAP and memory processing. Ideally, it is best to compare hippocampal IAP mRNA levels before and after training in the same animals or to compare IAP mRNA levels between trained and untrained individuals. However, the first suggestion is apparently impossible to implement. The second is also unfeasible because shock stimulus is an essential component of the training procedure. It is difficult to distinguish the trained and untrained groups without including the shock stimulus, although in the control study we have demonstrated that the IAP mRNA level was not different between the 
shocked animals and the unshocked controls. To overcome this difficulty, we have now considered an alternative approach for the IAP overexpression design, and these studies, along with other control experiments, are currently under investigation. On the other hand, we have chosen animals with retention scores of 600 sec and $<80 \mathrm{sec}$ for the present study. This cutoff provides the advantage of assuring good retention versus poor retention rats. It does not necessarily mean that those animals with a retention score falling between 80 and $600 \mathrm{sec}$ did not learn; instead, it is most likely that these animals were in a state of an approachavoidance conflict (dark vs shock) during the retention test. This suggestion is made on the basis of the finding that the memory retention of the animal improves as the shock intensity increases within a moderate intensity range (Riess, 1970). Accordingly, the number of animals showing middle retention scores decreases. Moreover, there were no apparent differences in other behavioral aspects between the good-memory and poor-memory rats, such as their responses to handling stress (our unpublished observations).

To further demonstrate the relationship between IAP mRNA expression and memory function, we have conducted the IAP regulation study. NMDA is known as an agonist for the NMDA type of glutamate receptors. Activation of NMDA receptors has been shown to be involved in many forms of learning and memory (Izquierdo, 1991) as well as LTP (Collingridge and Bliss, 1995). At the subcellular level, activation of the NMDA receptor induces a number of biochemical events, including $\mathrm{Ca}^{2+}$ influx, protein phosphorylation, nitric oxide synthesis, and immediateearly gene expression (Connor et al., 1988; Cole et al., 1989; Bading and Greenberg, 1991; Chetkovich et al., 1991; Nei et al., 1996). Recently, the effect of NMDA receptor activation at the intercellular level is emerging. Fazeli and colleagues (Fazeli et al., 1994; Wang et al., 1992) have demonstrated that the NMDAdependent increase in neuronal cell adhesion molecules and amyloid precursor protein follows the induction of LTP in the dentate gyrus of rats. The induction of IAP mRNA by NMDA in the present study together with the above results further supports the role of IAP gene expression in memory processing. In addition to NMDA, both amphetamine and carbachol are well known to facilitate memory processing. Amphetamine was suggested to improve memory retention through activation of the adrenergic receptors, and possibly finally via activation of NMDA receptors in the hippocampus (Lee et al., 1993; Cammarota et al., 1995; Izquierdo et al., 1995). Carbachol should act directly on muscarinic cholinergic receptors to facilitate memory. In the present study, we found that, similar to the effect of NMDA, amphetamine markedly increased the IAP mRNA level in the hippocampus. However, carbachol injection was without such an effect. These results together suggest that NMDA and amphetamine may act through the enhancement of cell adhesion to extracellular matrix proteins to facilitate memory formation, whereas the effect of carbachol is not mediated through the IAP signaling pathway. Last, application of the IAP antisense oligonucleotide impaired memory retention and hippocampal LTP in rats. Although the distribution of antisense oligonucleotide in the dentate gyrus is not directly examined in the present study, in another report Schmidt et al. (1995) demonstrated a successful diffusion of labeled antisense oligonucleotide in the endomeningeal cell layer after intraperimeningeal cavity injection in goldfish. The pattern of antisense penetration and distribution in the mammalian brain should be examined further.

In summary, with use of the PCR differential display method we have identified, cloned, and sequenced the IAP gene in the rat hippocampus. Both quantitative RT-PCR and in situ hybridization analyses have demonstrated a higher expression of IAP mRNA level in rats showing good retention performance. Both NMDA and amphetamine, which are known to facilitate memory retention in rats, also significantly increased IAP mRNA level in the hippocampus. On the other hand, the IAP antisense oligonucleotide markedly impaired memory retention and decreased the magnitude of LTP. This has been the first study to identify specific genes associated with memory formation of inhibitory avoidance learning in mammals. Other candidate genes are currently under investigation.

\section{REFERENCES}

Bading H, Greenberg ME (1991) Stimulation of protein tyrosine phosphorylation by NMDA receptor activation. Science 253:912-914.

Bahr BA, Lynch G (1992) Purification of an Arg-Gly-Asp selective matrix receptor from brain synaptic plasma membranes. Biochem J 281:137-142.

Bahr BA, Sheppard A, Lynch G (1991a) Fibronectin binding by brain synaptosomal membranes may not involve conventional integrins. NeuroReport 2:13-16.

Bahr BA, Sheppard A, Vanderklish PW, Bakus BL, Capaldi D, Lynch G (1991b) Antibodies to the alpha $\mathrm{v}$ beta 3 integrin label a protein concentrated in brain synaptosomal membranes. NeuroReport 2:321-324.

Bahr BA, Staubli U, Xiao P, Chun D, Ji ZX, Esteban ET, Lynch G (1997) Arg-Gly-Asp-Ser-selective adhesion and the stabilization of long-term potentiation: pharmacological studies and the characterization of a candidate matrix receptor. J Neurosci 17:1320-1329.

Brown E, Hooper L, Ho T, Gresham H (1990) Integrin-associated protein: a $50 \mathrm{kDa}$ plasma membrane antigen physically and functionally associated with integrins. J Cell Biol 111:2785-2794.

Cammarota M, Izquierdo I, Wolfman C, Levi de Stein M, Bernabeu R, Jerusalinsky D, Medina JH (1995) Inhibitory avoidance training induces rapid and selective changes in ${ }^{3}[\mathrm{H}] \mathrm{AMPA}$ receptor binding in the rat hippocampal formation. Neurobiol Learn Mem 64:257-264.

Campbell IG, Freemont PS, Foulkes W, Trowsdale J (1992) An ovarian tumor marker with homology to vaccinia virus contains an IgV-like region and multiple transmembrane domains. Cancer Res 52:5416-5420.

Castellucci VF, Kennedy TE, Kandel ER, Goelet P (1988) A quantitative analysis of 2-D gels identifies proteins in which labeling is increased following long-term sensitization in Aplysia. Neuron 1:321-328.

Chetkovich DM, Gray R, Johnston D, Sweatt JD (1991) N-methyl-Daspartate receptor activation increases cAMP levels and voltage-gated $\mathrm{Ca}^{2+}$ channel activity in area CA1 of hippocampus. Proc Natl Acad Sci USA 88:6467-6471.

Cole AJ, Saffen DW, Baraban JM, Worley PF (1989) Rapid increase of an immediate early gene messenger RNA in hippocampal neurons by synaptic NMDA receptor activation. Nature 340:474-476.

Collingridge GL, Bliss-TVP (1995) Memories of NMDA receptors and LTP. Trends Neurosci 18:54-56.

Connor JA, Wadman WJ, Hockberger PE, Wong RK (1988) Sustained dendritic gradients of $\mathrm{Ca}^{2+}$ induced by excitatory amino acids in CA1 hippocampal neurons. Science 240:649-653.

Davis HP, Squire LR (1984) Protein synthesis and memory: a review. Psychol Bull 96:518-559.

DeFreitas MF, Yoshida CK, Frazier WA, Mendrick DL, Kypta RM, Reichardt LF (1995) Identification of integrin alpha 3 beta 1 as a neuronal thrombospondin receptor mediating neurite outgrowth. Neuron 15:333-343.

Doyle E, Nolan PM, Bell R, Regan CM (1992) Hippocampal NCAM180 transiently increases sialylation during the acquisition and consolidation of a passive avoidance response in the adult rat. J Neurosci Res 31:513-523.

Fazeli MS, Breen K, Errington ML, Bliss TV (1994) Increase in extracellular NCAM and amyloid precursor protein following induction of long-term potentiation in the dentate gyrus of anaesthetized rats. Neurosci Lett 169:77-80.

Fox GB, O'Connell AW, Murphy KJ, Regan CM (1995) Memory consolidation induces a transient and time-dependent increase in the frequency of neural cell adhesion molecule polysialylated cells in the adult rat hippocampus. J Neurochem 65:2796-2799. 
Frohman MA, Dush MK, Martin GR (1988) Rapid production of fulllength cDNAs from rare transcripts: amplification using a single genespecific oligonucleotide primer. Proc Natl Acad Sci USA 85:8998-9002.

Gao AG, Lindberg FP, Finn MB, Blystone SD, Brown EJ, Frazier WA (1996) Integrin-associated protein is a receptor for the C-terminal domain of thrombospondin. J Biol Chem 271:21-24.

Glanzman DL, Kandel ER, Schacher S (1989) Identified target motor neuron regulates neurite outgrowth and synapse formation of aplysia sensory neurons in vitro. Neuron 3:441-450.

Goelet P, Castellucci VF, Schacher S, Kandel ER (1986) The long and the short of long-term memory-a molecular framework. Nature 322:419-422.

Grotewiel MS, Beck CDO, Wu KH, Zhu XR, Davis RL (1998) Integrin-mediated short-term memory in Drosophila. Nature 391:455-460.

Huang AM, Lee EHY (1995) Role of hippocampal nitric oxide in memory retention in rats. Pharmacol Biochem Behav 50:327-332.

Izquierdo I (1991) Role of NMDA receptors in memory. Trends Pharmacol Sci 12:128-129.

Izquierdo I, Fin C, Schmitz PK, Da Silva RC, Jerusalinsky D, Quillfeldt JA, Ferreira MB, Medina JH, Bazan NG (1995) Memory enhancement by intrahippocampal, intraamygdala, or intraentorhinal infusion of platelet-activating factor measured in an inhibitory avoidance task. Proc Natl Acad Sci USA 92:5047-5051.

Jansen JG, Vrieling H, van Zeeland AA, Mohn GR (1992) The gene encoding hypoxanthine-guanine phosphoribosyltransferase as target for mutational analysis: PCR cloning and sequencing of the cDNA from the rat. Mutat Res 266:105-116.

Keller F, Schacher S (1990) Neuron-specific membrane glycoproteins promoting neurite fasciculation in Aplysia californica. J Cell Biol 111:2637-2650.

Lee EHY, Ma YL (1995) Amphetamine enhances memory retention and facilitates norepinephrine release from the hippocampus. Brain Res Bull 37:411-416.

Lee EHY, Hung HC, Lu KT, Chen WH, Chen HY (1992) Protein synthesis in the hippocampus associated with memory facilitation by corticotropin-releasing factor in rats. Peptides 13:927-937.

Lee EHY, Lee CP, Wang HI, Lin WR (1993) Hippocampal CRF, NE, and NMDA system interactions in memory processing in the rat. Synapse 14:144-153.

Liang P, Pardee AB (1992) Differential display of eukaryotic messenger RNA by means of the polymerase chain reaction. Science 257:967-971.

Liang P, Averboukh L, Pardee AB (1993) Distribution and cloning of eukaryotic mRNAs by means of differential display: refinements and optimization. Nucleic Acids Res 21:3269-3275.

Lindberg FP, Gresham HD, Schwarz E, Brown EJ (1993) Molecular cloning of integrin-associated protein: an immunoglobulin family member with multiple membrane-spanning domains implicated in alpha $\mathrm{v}$ beta 3-dependent ligand binding. J Cell Biol 123:485-496.

Mawby WJ, Holmes CH, Anstee DJ, Spring FA, Tanner MJ (1994) Isolation and characterization of CD47 glycoprotein: a multispanning membrane protein which is the same as integrin-associated protein (IAP) and the ovarian tumour marker OA3. Biochem J 304:525-530.

Murphy KJ, O'Connell AW, Regan CM (1996) Repetitive and transient increases in hippocampal neural cell adhesion molecule polysialylation state following multitrial spatial training. J Neurochem 67:1268-1274.

Nei K, Matsuyama S, Shuntoh H, Tanaka C (1996) NMDA receptor activation induces glutamate release through nitric oxide synthesis in guinea pig dentate gyrus. Brain Res 728:105-110.

Reichardt LF, Tomaselli KJ (1991) Extracellular matrix molecules and their receptors: functions in neural development. Annu Rev Neurosci 14:531-570.

Reinhold MI, Lindberg FP, Plas D, Reynolds S, Peters MG, Brown EJ (1995) In vivo expression of alternatively spliced forms of integrinassociated protein (CD47). J Cell Sci 108:3419-3425.

Riess D (1970) Sidman avoidance in rats as a function of shock intensity and duration. J Comp Physiol Psychol 73:481-485.

Rose SP (1995) Cell-adhesion molecules, glucocorticoids and long-termmemory formation. Trends Neurosci 18:502-506.

Schmidt R (1995) Cell-adhesion molecules in memory formation. Behav Brain Res 66:65-72.

Schmidt R, Brysch W, Rother S, Schlingensiepen KH (1995) Inhibition of memory consolidation after active avoidance conditioning by antisense intervention with ependymin gene expression. J Neurochem 65:1465-1471.

Staubli U, Vanderklish P, Lynch G (1990) An inhibitor of integrin receptors blocks long-term potentiation. Behav Neural Biol 53:1-5.

Tamkun JW, DeSimone DW, Fonda D, Patel RS, Buck C, Horwitz AF, Hynes RO (1986) Structure of integrin, a glycoprotein involved in the transmembrane linkage between fibronectin and actin. Cell 46:271-282.

Tang YP, Kashon ML, Sisk CL (1997) Brain regional-specific regulation of luteinizing hormone-releasing hormone messenger ribonucleic acid in the male ferret: interactions between pubertal maturation and testosterone. Endocrinology 138:4740-4747.

Tully T (1996) Discovery of genes involved with learning and memory: an experimental synthesis of Hirschian and Benzerian perspectives. Proc Natl Acad Sci USA 93:13460-13467.

Wang S, Lees GJ, Bock E, Hamberger A, Haglid KG (1992) Biphasic changes in NCAM level after an NMDA lesion to the hippocampal formation: a quantitative dot-immunobinding assay. J Neurosci Res 33:626-630.

Wayner MJ, Armstrong DL, Polan-Curtain JL, Denny JB (1993) Role of angiotensin II and $\mathrm{AT}_{1}$ receptor in hippocampal LTP. Pharmacol Biochem Behav 45:455-464.

Weiler IJ, Hawrylak N, Greenough WT (1995) Morphogenesis in memory formation: synaptic and cellular mechanisms. Behav Brain Res 66:1-6.

Xiao P, Bahr BA, Staubli U, Vanderklish PW, Lynch G (1991) Evidence that matrix recognition contributes to stabilization but not induction of LTP. NeuroReport 2:461-464.

Yoshihara Y, Oka S, Ikeda J, Mori K (1991) Immunoglobulin superfamily molecules in the nervous system. Neurosci Res 10:83-105. 